ljtihad, Jurnal Wacana Hukum Islam dan Kemanusiaan

Vol. 18, No. 1 (2018), pp. 17-31, doi : 10.18326/ijtihad.v18i1.17-31

\title{
Islam dan perubahan sosial: Gerakan sedeqah lima ratus rupiah dan perubahan sosial di kabupaten Sukabumi
}

Iji Jaelani

Program Studi Religious Studies Pascasarjana UIN Sunan Gunung Djati Bandung

Email: ïjaelani90@gmail.com

\author{
Ahmad Ali Nurdin \\ Fakultas Ilmu Sosial dan Ilmu Politik, UIN Sunan Gunung Djati Bandung \\ Email:nurdinster@gmail.com \\ DOI: 10.18326/ijtihad.v18i1.17-31
}

In the study of religions, the concept of charity is an integral part of the core, especially with regard to the transformation of religion as a social change. Such concept can be seen in the five hundred rupiah denomination movement in Sukabumi district. This movement began in 2000 involving many parties including religious institutions, and the wider community. used to make social changes, even helped initiate the birth of public policy regarding zakat, infak, and shodaqoh in Sukabumi District. The method used to conduct this research is the theory of religious experience (thought, action, and fellowship) and the theory of hegemony. From this study, the author analyzes the five hundred-dollar alms movement is a form of expression of religious experience inspired by religious thought nahdlatul (fikrah nahdliyah and harakah nahdliyah) and has a great social impact on the change of society. This political, five-hundred-dollar alms movement uses a strategy hegemony, the intellectual leadership and moral leadership of Abdul Basith as the founder to volunteers and the government to launch its activities until the birth of social change in the field of regional registration on the management of zakat, infaq, and shodaqoh.

Dalam kajian agama-agama, konsep sedekah merupakan bagian inti yang tidak bisa dilepaskan, khususnya berkaitan dengan transformasi agama sebagai perubahan sosial.Konsep demikian bisa dilihat pada gerakan sedekah lima ratus rupiah di kabupaten Sukabumi. Gerakan ini dimulai pada tahun 2000 melibatkan banyak pihak meliputi lembaga agama, dan masyarakat luas. Digunakan untuk melakukan perubahan sosial, bahkan turut menginisiasi lahirnya kebijakan publik mengenai zakat, 
ljtihad: Jurnal Wacana Hukum Islam dan Kemanusiaan, Volume 18, No. 1, Juni 2018: 17-31

infak, dan shodaqoh di Kabupaten Sukabumi. Metode yang digunakan untuk melakukan penelitian ini ialah teori pengalaman keagamaan (pemikiran, tindakan, dan persekutuan) dan teori hegemoni. Dari penelitian tersebut, penulis menganalisis gerakan sedekah lima ratus merupakan bentuk ekspresi pengalaman keagamaan yang diinspirasi dari pemikiran keagamaan nahdlatul (fikrah nahdliyah dan harakah nahdliyah) dan memiliki dampak sosial yang besar pada perubahan masyarakat. Secara politik, gerakan sedekah lima ratus rupiah ini menggunakan strategi hegemoni, yakni kepemimpinan intelektual dan kepemimpinan moral dari Abdul Basith sebagai pendiri kepada relawan dan pemerintah untuk melancarkan kegiatannya hingga lahirnya lahirnya perubahan social di bidang registrasi peraturn daerah tentang pengelolaan zakat, infaq, dan shodaqoh.

Keywords: charity; religious experience; hegemony; social change

\section{Pendahuluan}

Dalam kajian agama-agama, konsep sedekah merupakan bagian inti yang tidak bisa dilepaskan, khususnya berkaitan dengan transformasi agama sebagai perubahan sosial (UU No 23 Tahun 2011 tentang Zakat). Bahkan, Menurut Ahmad Gaus, semua agama mengajarkan pemeluknya untuk berderma (bersedekah), yakni mengeluarkan sebagian hartanya untuk orang lain yang kekurangan (Ahmad Gaus, 2008: 2). Dalam agama Kristen, konsep sedekah bernama sedekah (Kitab Matius 6 1:4) dan merupakan bagian inti dari cinta kasih (Ligon Duncan, Ten Principles of Christian Giving, 5 Desember 2011). Begitu juga dalam Hindu konsep sedekah dikenal dengan nama dana punia, yakni pemberian yang baik dan suci. Dalam agama Budha, konsep sedekah disebut berdana, yakni melepas sesuatu yang dimiliki dengan tulus ikhlas kepada yang membutuhkan dengan tujuan yang baik (K.Wijaya Mukti, 1993: 129). Adapun dalam Islam, sedekah dikenal dengan nama shodaqoh, yaitu mengeluarkan harta di jalan Allah sebagai bukti kejujuran atau kebenaran keimanan seseorang (Q.S. Al-Baqarah: 261). Pada point inilah sedekah memegang peranan kunci dalam mewujudkan fungsi agama dalam perubahan sosial.

Dalam Islam, konsep sedekah, khususnya zakat (sedekah wajib) merupakan konsep yang sangat pokok, menjadi bagian dari rukun Islam dan turunnya perintah tersebut hampir selalu beriringan dengan perintah shalat. Menurut Syamsul Huda, dari 30 buah kata zakat yang disebutkan dalam Al Qur'an, sebanyak 27 buah di antaranya (90\%) ditemukan bergandengan dengan shalat (Huda, 2017: 43). Akan tetapi pada praktiknya, zakat masih sulit dilaksanakan dibanding shalat. Fenomena ini mengakibatkan terjadinya disfungsi agama bagi perubahan 
Islam dan perubahan sosial: Gerakan sedeqah lima ratus rupiah dan perubahan sosial... (lji Jaelani)

sosial, yakni keyakinan agama pemeluknya tidak berbanding lurus dengan kepedulian dan pemberdayaan sosial masyarakat Islam.

Berkaitan dengan problem di atas, gerakan sedekah lima ratus rupiah di Kabupaten Sukabumi menarik untuk diteliti. Pertama, gerakan sedekah lima ratus rupiah merupakan pendidikan zakat sebelum nisab (jatuh tempo). Gerakan sedekah ini bermula dari kegelisahan KH.R. Abdul Basith mengenai ketimpangan ajaran agama, khususnya mengenai minimnya praktek zakat di Desa Naggerang, Kec. Cicurug, Kab. Sukabumi (Huda, 2017: 19). Padahal, zakat merupakan instrumen penting dalam agama untuk melakukan pemberdayaan masyarakat.

Kedua, pada sisi dampak, gerakan sedekah lima ratus rupiah telah digunakan untuk pemberdayaan sosial masyarakat. Misalnya, pembiayaan gaji marbot dan guru ngaji, penyelenggaraan peringatan hari-hari besar dalam Islam pelayanan rekening listrik untuk masjid, pengembangaan pesanatren konservasi, santunan keluarga duka, pelayanan kesehatan gratis, raskin untuk janda jompo, bantuan persalinan bagi ibu bersalin, santunan yatim piatu dan jompo, beasiswa anak yatim, pembangunan dan pengembangan poliklinik dan kesehatan cuma-cuma, lampunisasi jalan-jalan kecil, serta agropreneur. Dari berbagai pemberdayaan tersebut, gerakan sedekah lima ratus rupiah mendorong masyarakat yang awalnya mustahiq bisa berubah menjadi muzaki, serta turut serta menjadi gerakan dakwah filantropi, yakni gerakan agama yang konsentrasi pada pengembangan misi kemanusiaan (Huda, 2017: 109-113).

Ketiga, secara aktor, gerakan yang sudah berjalan selama 17 tahun ini melibatkan banyak pihak, baik KH R. Abdul Basith sebagai inisiator gerakan sedekah, Lazisnu Kab. Sukabumi, struktur pemerintahan, dan masyarakat.Keterlibatan para pihak tersebut, meskipun terjadi dalam jangka waktu yang lama, memainkan peranan yang sangat signifikan. Di antara semua aktor tersebut, terdapat beberapa konsep dan aktor kunci dan yang berhasil membuat gerakan ini berjalan kontinyu.

Keempat, gerakan yang dimulai dari satu desa ini turut menginisiasi lahirnya kebijakan anjuran sedekah bagi pengusaha dan pekerja serta peraturan bupati mengenai infak sedekah masyarakat. Peraturan pemerintah yang diinisiasi oleh gerakan sedekah lima ratus rupiah adalah Surat Edaran Bupati No. 3 Tahun 2016 tentang Gerakan Shalat Subuh di Massjid, Surat Edaran Bupati No. 1 Tahun 2016 tentang Pengumpulan Zakat Infak Sedekah (ZIS) 
ljtihad: Jurnal Wacana Hukum Islam dan Kemanusiaan, Volume 18, No. 1, Juni 2018: 17-31

Pengusaha Penyedia Barang dan Jasa, serta Peraturan Bupati No. 35 tahun 2016 tentang Pengelola Infak Sedekah Bantuan Sosial Keagamaan Lainnya Berbasis Masyarakat. Peraturan tersebut dilakukan Bupati Kab.Sukabumi untuk menjadikan Sukabumi sebagai daerah berbasis zakat, infak, dan sedekah.

Dari uraian di atas, ada dua kerangka pendekatan yang bisa digunakan. Pertama, pendekatan spirit pengalamaan keagamaan yang menjadi landasan spirit gerakan sedekah. Kedua, pendekatan pengaruh kepemimpinan untuk melihat aktor yang terlibat dalam mensukseskan gerakan sedekah lima ratus rupiah sampai menjadi sebuah kebijakan.

\section{Teori pengalaman keagamaandan hegemoni dalam gerakan sedekah lima ratus rupiah}

Untuk menjelaskan gerakan sedekah lima ratus rupiah, penulis menggunakan dua konsep, yakni teori Joachim Wach tentang religious experience (pengalaman keagamaan) dan teori Gramsci tentang Hegemoni. Teori pengalaman keagamaan digunakan untuk menganalisa prilaku keberagamaan masyarakat Desa Nanggerang, Kec. Cicurug, Kab. Sukabumi dalam melakukan gerakan sedekah. Adapun teori hegemoni digunakan untuk menganalisa kekuatan pengaruh para actor dalam menggerakkan sedekah di masyarakat Desa Nanggerang sampai meluas ke kecamatan lain dan menjadi kebijakan politik bupati Sukabumi.

Menurut Joachim Wach, pengalaman keagamaan adalah tanggapan terhadap apa yang dihayati sebagai Realitas Mutlak. Yang dimaksud dengan Realitas Mutlak adalah realitas yang menentukan dan mengikat segala-galanya (Wach, 1992: 44). Menurut Joachim Wach, hakikat pengalaman keagamaan dibagi menjadi 3 bentuk, yaitu thought (doktrin, pemikiran), practice (tindakan agama), dan fellowship (persekutuan, kelompok keagamaan) (Kahmad, 2000: 27-28). Pengalaman ini menjadi sangat penting dalam memahami landasan sehingga masyarakat begitu yakin akan kebenaran dan kebaikan sedekah serta memiliki kerelaan hati mensedekahkan 2,5\% pengasilannya.

Adapun hegemoni dalam bahasa Yunani kuno disebut engemonia, istilah yang digunakan untuk menunjukkan dominasi posisi yang diklaim oleh negara-negara kota terhadap negara lain yang sejajar (Hendarto, 1993: 73). Secara terminologi, hegemoni merupakan konsep yang menunjukkan sebuah kepemimpinan di suatu negara tertentu (Patria dan Arief, 2009: 115). Dalam konteks politik nasional, hegemoni misalnya pertaruhan pengaruh antara kekuasan 
Islam dan perubahan sosial: Gerakan sedeqah lima ratus rupiah dan perubahan sosial... (lji Jaelani)

negara berhadapan dengan kelompok oposisi. Dalam konteks keagamaan, hegemoni berarti pengaruh kepemimpinan lembaga NU, Muhammadiyah, dan Persis dalam menjawab permasalahan keagamaan di masyarakat.

Hegemoni sebenarnya merupakan elaborasai dari dua pratik kekuasaan, yakni kepemimpinan dan dominasi. Konsep kepemimpinan diambil dari persetujuan atau konsensus, sedangkan dominasi diambil dari kekuatan (force) atau paksaan. Dalam konteks ini, hegemoni sebagai sebuah pengaruh dijalankan melalui dua model kepemimpinan, yakni kepemimpinan moral dan kepemimpinan intelektual.Kedua model ini digunakan pada satu moment, kondisi di mana pemikiran dan praktik masyarakat menyatu dalam keadaan seimbang.

Masih menurut Gramsci, konsep hegemoni berada pada tiga formasi sosial masyarakat, yakni ekonomi, negara, dan masyarakat sipil. Pada konteks perubahan masyarakat inilah, sosok intelektual memegang peranan kunci dalam menyebarkan pengaruhnya.Gramsci sendiri membagi intelektual menjadi dua jenis, yakni intelektual tardisional dan intelektual organik. Intelektual tradisional merupakan kaum terdidik yang terlepas dari hubungan sosial yang menyertainya. Adapun intelektual organik merupakan kaum terdidik yang terlibat langsung dalam melakukan tugas intelektualitasnya untuk perubahan masyarakat. Teori hegemoni dipandang relevan dalam menjelaskan pengaruh actor intelektual organik yang menjadi motor gerakan sedekah serta peranan kepemimpinan intelektual dan moral dalam mempengaruhi masyarakat dan pembuat kebijakan. Hegemoni ini pula digunakan oleh kepala daerah di Kabupaten Sukabumi dalam mempercepat gerakan sedekah dalam skala yang lebih luas, melalui pengaruh kekuasaan politiknya, berupa surat edaran hingga peraturan bupati mengenai pengelolaan sedekah.

\section{Sejarah gerakan sedekah lima ratus rupiah di Kabupaten Sukabumi}

Gerakan sedekah lima ratus rupiah ini dimulai pada tahun 2000 ketika KH. R. Abdul Basith, ketua PCNU Kabupaten Sukabumi sekaligus pengasuh pondok pesantren Al Amin, Nanggerang, Cicurug Sukabumi, mengalami kegelisahan mengenai minimnya pelaksanaan zakat, padahal zakat merupakan salah satu rukun Islam. Begitu pula pada sisi dampak, jika saja zakat dilaksanakan oleh umat Islam, maka akan terjadi suatu kemanfaatan yang besar bagi umat Islam dan masyarakat secara umum (Huda, 2017: 43). 
ljtihad: Jurnal Wacana Hukum Islam dan Kemanusiaan, Volume 18, No. 1, Juni 2018: 17-31

Atas kegelisahan tersebut, Abdul Basith mengumpulkan dan menggerakkan para muballig dan dai untuk mulai mensosialisasikan zakat, infak dan sedekah di majelis taklim, pengajian, forum-forum tablilan (doa bersama ketika ada warga yang meninggal dunia), dan majelis istighatsah. Untuk lebih memasifkan gerakan sedekah, Abdul Basith membuat forum pengajian "suji" (subuh mengaji), yakni penguatan ajaran agama, sambil sosialisasi pentingnya sedekah. Bahkan, dari berbagai forum agama, gagasan pentingnya zakat, infak dan sedekah ini disebarluaskan ke kelompok masyarakat di lingkunga RT (Rukun Tetangga) dan RW (Rukun Warga). Untuk merealisasikan gagasan zakat, infak, dan sedekah, warga diminta membentuk pengurus zakat, infak, dan sedekah di lingkungannya masing-masing.

Point inti dari sosialisasi zakat, infak, dan sedekah ialah pendidikan bagi masyarakat untuk belajar mengeluarkan zakat sebelum nisab agar ketika pada saat nisab, masyarakat akan menjalankan syariat zakat secara sukarela. Atas pertimbangan ini, gagasan pendidikan zakat ini berwujud menjadi gerakan sedekah karena sedekah lebih luasa cakupannya dan bisa dilakukan kapan pun.

Adapun pilihan nominal Rp. 500 ialah hitungan prosentase 2,5\% dari rata-rata penghasilan masyarakat buruh tani lepas (petani yang tidak mempunyai tanah, hnya menggarap lahan milik orang lain), yakni Rp. 20.000/ hari (Huda, 2017, 28). Dari jumlah 1603 kepala keluarga di Desa Nanggerang, gerakan ini bisa menghasilkan pemasukan Rp. 28.000 .000 setiap bulan.

Pada awalnya, gerakan sedekah lima ratus rupiah ini hanya diikuti oleh 4 RW di Desa Nanggeran, akan tetapi seriring dengan konsisten dan massifnya sosialisasi, gerakan ini menyebar luas ke desa dan kecamatan lain di Sukabumi, bahkan mendapatkan payung hukum oleh Bupati untuk disebarluaskan ke perusahaan dan karyawan perusahaan di kabupaten Sukabumi.Hal ini dibuktikan melalui surat edaran Bupati kab. Sukabumi untuk melaksanakan shalat subuh berjamaah dan bersedekah, surat edaran, surat edaran bupati mengenai anjuran zakat, infak sedekah bagi pengusaha dan pekerja, serta peruaturan bupati mengenai pengelolaan infak dan sedekah bagi masyarakat.

\section{Pengalaman keagamaan masyarakat dalam menjalankan gerakan sedekah lima ratus rupiah}

Secara sosiologis, kelompok masyarakat yang terlibat dalam gerakan lima ratus rupiah merupakan kelompok masyarakat yang berafiliasi dengan organisasi keagamaan Nahdlatul 
Islam dan perubahan sosial: Gerakan sedeqah lima ratus rupiah dan perubahan sosial... (lji Jaelani)

ulama. Hal ini dibuktikan dengan seorang inisiator KH.R Abdul Basith sebagai ketua PCNU Kab.Sukabumi dan lembaga NU Care-Lazisnu (lembaga amil zakat, infak, shadaqah NU) sebagai pengelolanya. Selain itu, kelompok masyarakatnya berada di bawah binaan Nahdlatul Ulama sehingga pemikiran, tindakan, dan persekutuannya pun menggunakan model ke NU-an.

Dengan meminjam pendekatan Joachim Wach, konsep religious experience (pengalaman keagamaan) di organisasi Nahdlatul Ulama memiliki dua aspek, yakni aspek pemikiran (fikrah nahdliyah) dan aspek gerakan (harakah nahdliyah). Pada aspek pemikiran, NU memiliki prinsip tawassutiyyah (moderasi), tatawmuriyah (dinamisasi), dan manhajiyah (metodologi) (Huda, 2017: 10). Pada prinsip moderasi, NU menghindari sejauh mungkin konsep ekstrimisme, baik ekstrimisme agama, ekonomi maupun politik. Ekstrimsisme pemikiran keagamaan berbentuk pemikiran jabariyah dan qadariyah. Ekstrimisme ekonomi berbentuk kapitalisme sosialisme, begitu pula ekstrimisme berbentuk liberalisme komunisme.

Prinsip dinamisasi dalam tubuh NU sendiri diambil dari kaidah al muhäfaz̧ah alāal-qadim as sălih wal akhdhu bi al-jadid al-așlah (melestarikan tradisi lama yang baik dan mengambil hal baru yang lebih baik) (Huda, 2017: 10). Konsep ini dijadikan pakem dalam merespon hubungan antara agama dengan budaya, begitu juga antara budaya lama dengan budaya baru sehingga semua dimensi tersebut bisa berdialog dan berjalan harmonis. Adapun prinsip manhaji yang digunakan dengan cara melakukan kontekstualisasi teks fiqih, mengubah mazhab qauli ke mazhab manhaji, verifikasi antara pokok dan cabang, menghadirkan fiqih sebagai etika sosial, serta pemahaman filosofis atas konteks budaya (Kristeva, 160).

Adapun pengalaman keagamaan dalam bentuk praktek keagamaan NU dilakukan melalui sikap himāyah (perlindungan) dan is lähiyah (perbaikan), selain sikap toleran, moderat, dan adil. Bahkan, Maruf Amin menyatakan sikap islahiyah ini perlu dilakukan terus menerus untuk menemukan konteksnya yang lebih baru dan inovatif. Maka, konsep al mubafazah ala al qadim as- sălib wal akhdhu bi al-jadid al-aslah diperbaharui menjadi al mubafaz̧ah ala al-qadim as- sălih wal akhdhu bi al-jadid al- ashlah, al ișlāh ila mā ghair al- aslah thumma al- aslah fal aslah (melestarikan tradisi lama yang baik dan mengambil hal baru yang lebih baik, memperbaiki apa yang belum menjadi lebih baik serta perbaikan terus menerus) (Huda, 2017: 11). 
ljtihad: Jurnal Wacana Hukum Islam dan Kemanusiaan, Volume 18, No. 1, Juni 2018: 17-31

Sementara pengalaman keagamaan dalam bentuk perkumpulan dilakukan melalui banyak badan otonom, baik budaya, pertanian, perekonomian dan kepemudaan, dan lainnya. Untuk pengelolaan zakat secara khusus, NU membentuk lazisnu pada 2004 di Boyolali, pada 2016 lazisnu melakukan rebranding menjadi NU Care lazisnu dengan sistem manajemen ISO 9001:2015 dengan nomor sertifikat izin 49224 (https://nucarelazisnu.org/sejarah). Pada aspek ini, Rais Am NU, Makruf Amin menyerukan konsep harakah nabdiyah lizzakah, yakni gerakan kebangkitan kaum nahdliyin untuk berzakat. Konsep ini mendorong terjadinya redistribusi pendapatan agar kesejahteraan tidak hanya berputar di tangan orang-orang kaya semata (Huda, 2017, 11).

Berkaitan dengan pengalaman keagamaan oragnisasi Nahdlatul Ulama, masyarakat Desa Nanggerang yang menganut faham keagamaan sunni dan berafiliasi dengan Nahdlatul Ulama, pemikiran keagamaan dan gerakan keagamaannya mengikuti pemikiran ke-Nu-an, baik pemikiran keagamaan secara umum maupun pemikiran mengenai kesadaran berzakat dan bersedekah. Karena itu, secara umum masyarakat sudah tidak begitu asing dengan konsep kesimbangan mengenai hablun min Allah (hubungan manusia denggan Tuhan) dan hablun min an-nas (hubungan manusia dengan manusia lain), yaitu keimanan individual harus berbanding lurus dengan kesalihan sosial (QS Ali Imran: 112).

Dari pemikiran tersebut, maka sedekah lima ratus rupiah merupakan bagian dari ibadah seperti halnya shalat sehingga gerakan ini dipandang sebagai bagian dari panggilan agama. Keseimbangan (tawasut) antara hubungan vertikal dengan Tuhan dan hubungan horizontal dengan manusia lain ditegaskan dalam Al Quran mengani penyebutan kata shalat dan zakat secara beriringan. Konsep shalat dan zakat merupakan dua konsep yang 90\% selalu bergandengan. Akan tetapi prakteknya banyak terdapat ketimpangan. Pertama, shalat lebih banyak disosialisasikan sejak usia dini ketimbang zakat. Kedua, kesadaran untuk shalat lebih tinggi ketimbang zakat. Ketiga, frekuensi shalat lebih tinggi ketimbang zakat. Fenomena ini menyebabkan munculnya kesenjangan untuk memperkuat spiritual, tapi rendah kepedulian sosial. Secara pemikiran, gerakan sedekah lima ratus merupakan kontekstualisasi pemikiran keagamaan di kalangan NU, yakni keadilan dan keseimbangan, dan moderasi (Huda, 2017: 46-48).

Meskipun secara pemikiran gerakan sedekah lima ratus rupiah ini diinspirasi dari pemikiran ke NU-an, akan tetapi secara praktek justeru gerakan sedekah lima ratus rupiah ini empat 
Islam dan perubahan sosial: Gerakan sedeqah lima ratus rupiah dan perubahan sosial... (lji Jaelani)

tahun lebih dahulu ketimbang kelahiran lazisnu di tubuh NU. Artinya, kesadaran keagamaan untuk melakukan zakat dan sedekah telah muncul dari kesadaran masyarakat sebelum ada adanya lembaga agama yang melaksanakannya.

Untuk memanifestasikan pemikiran tersebut, maka sosialisasi zakat dan sedekah dipandang perlu lebih diintensifkan seperti halnya shalat. Pertama, sosialisasi zakat dan sedekah perlu dilakukan kepada anak usia dini. Kedua, pengumpulan zakat perlu dikakukan secara kolektif bukan oleh perorangan. Ketiga, perlunya peningkatan frekuensi zakat sehingga tidak hanya dilakukan pada bulan Ramadhan (Huda, 49-51).

Sebelum mengajak sedekah kepada ibu-ibu di majelis taklim, Abdul Basith melontarkan pertanyaan kepada jamaah mengenai keberatan tidaknya menyisihkan Rp. 500 dari jatah nasi bagi keluarga. Ketika jamaah mengatakan tidak keberataan, Abdul Basith mempertanyakan kesediaan menyisihkan Rp. 500 dari pengeluaran harian keluarga. Dari kesamaan pandangan tersebut, ibu-ibu memiliki kesepakatan untuk menyisihkan uangnya ke dalam toples yang disediakan pengurus ZIS (zakat, infak, sedekah) di rumah masing-masing.Uang tersebut diambil setiap minggu oleh pengurus ZIS, biasanya ibu-ibu Fatayat atau Muslimat (badan otonom perempuan di organisasi Nahdlatul Ulama) karena mereka dipandang lebih memiliki waktu luang. Sebelum adanya lembaga Lazisnu (lembaga ZIS di tubuh Nahdlatul Ulama), gerakan ini dikelola secara swadaya oleh masyarakat. Akan tetapi, pada tahun 2004 ketika NU mendirikan lazisnu, maka pengelolaan sedekah ini dilimpahkan kepada Lazisnu.

Untuk melakukan pengelolaan sedekah secara optimal, gerakan sedekah Rp. 500 dilakukan melalui prinsip “terima-kasih", yakni ketika menerima penghasilan, langsung memberi sedekah. Kedua, larangan menerima amplop, yakni ketika melakukan ceramah dan sosialisasi, dilarang menerima bayaran dari undangan tersebut.

\section{Peran hegemoni tokoh dan dampak gerakan sedekah lima ratus rupiah dalam pe- rubahan sosial}

Sebagai sebuah gerakan keagamaan, analisa pengalaman keagamaan tidak cukup mampu menginterpretasikan praktek di lapangan secara menyeluruh, terutama analisa aktor dan kepentingan, serta singgungannya dengan kekuasaan dan kebijakan politik. Sebagai sebuah gerakan sosial keagamaan dalam sekala luas, khususnya di Kabupaten Sukabumi, paling tidak Abdul Basith menggunakan logika kekuasaan, baik kekuasaan di tubuh PCNU Kab. 
ljtihad: Jurnal Wacana Hukum Islam dan Kemanusiaan, Volume 18, No. 1, Juni 2018: 17-31

Sukabumi, maupun Pemerintah Daerah. Kedua kekuasaan itu memungkinkan terjadinya percepatan perubahan melalui serangkaian kharisma dan regulasi.

Berkaitan dengan konsep ini, terutama mengurai tokoh-tokoh yang berperan dalam melaksanakan gerakan sedekah dan perubahan social yang ditimbulkannya, penulis menganalisis dua hal, yakni analisis tokoh yang terlibat, dan hegemoni yang dilakukan. Analisis tokoh dilakukan untuk memahami para pihak yang terlibat, baik tokoh yang mempengaruhi dan dipengaruhi, serta tokoh elit dan massa. Sedangkan analisis hegemoni dilakukan untuk memaparkan sejauh mana peran yang dimainkan sehingga gerakan sedekah lima ratus rupiah ini tetap bertahan selama belasan tahun, bahkan berkembang.

Secara garis besar, gerakan sedekah ini ditopang oleh lima tokoh.Tokoh pertama ialah Abdul Basith, inisiator gerakan sedekah sekaligus pimpinan pesantren Al Amin Desa Nanggerang, Cicurug, Kab. Sukabumi sekaligus ketua PCNU Kab.Sukabumi. Tokoh kedua ialah relawan, terdiri dari kelompok PKK, ibu-ibu fatayat dan muslimat, kelompok tani, kelompok ekstrakulikuler di sekolah, dan pengurus ZIS. Relawan merupakan ujung tombak berjalan tidaknya gerakan sedekah karena kelompok ini langsung bersentuhan dengan massa. Ketiga, pemerintah daerah, baik pemerintahan RT RW, kepala desa, sampai bupati.Kelompok ini menjadi stimulus dan legitimasi gerakan sedekah.

Dalam mengawali gerakan sedekah, Abdul Basith sendiri menyandang dua kekuasaan sekaligus. Pertama, ia adalah pimpinan pesantren di Desa Nanggerang. Kedua, ia merupakan ketua PCNU Kab. Sukabumi. Artinya, sejak awal ia sudah memiliki modal sosial di masyarakat, baik kharisma ketokohan agama dan kepemimpinan moral. Fakta inilah yang memungkinkan ia tidak terlalu kesulitan mengumpulkan para penceramah untuk mensosialisasikan zakat dan sedekah di sela sela pengajian.

Cara yang ditempuh Abdul Basith untuk memperluas hegemoninya ialah menggunakan dua cara. Cara pertama menggunakan kepempimpinan intelektual, dimulai dari teks ayat $\mathrm{Al}$ Quran tentang kewajiban zakat sampai sebuah inisiasi sedekah Rp. 500. Spirit dan legitimasi agama merupakan kekuatan besar dalam mendorong masyarakat bersedekah setiap hari. Sebagaimana agama dipahami sebaga jalan keselamatan, maka sedekah yang dilandasi agama akan meningkatkan dorongan memberi agar bisa menjadi jalan keselamatan hidup. Adapun perluasan gagasan tersebut dilakukan melalui ceramah dan sosialisasi zakat dari satu pengajian 
Islam dan perubahan sosial: Gerakan sedeqah lima ratus rupiah dan perubahan sosial... (lji Jaelani)

ke pengajian yang lain, bahkan untuk melakukan kristalisasi ajakan berzakat, Abdul Basith mendirikan program subuh mengaji (suji), secara bergiliran dari satu masjid ke masjid lain, sambil melakukan sosialisasi zakat dan sedekah.

Cara kedua yang dilakukan Abdul Basith adalah menggunakan kekuasaannya sebagai pimpinan di tubuh NU Kab.Sukabumi. Untuk membangun komunikasi elit kepada elemen lain, baik perusahaan maupun pemerintah. Pengaruh kepemimpinan agama yang membuat dirinya tidak terlalu kesulitan ketika mengajak para penceramah untuk mensosialisasikan zakat. Melalui kepemimpinan NU pula, ia lebih leluasa membangun jaringan dan pengaruh di lingkungan elit Kab. Sukabumi, baik pejabat desa, pejabat daerah, maupun pimpinan perusahaan.

Tokoh penentu kedua adalah kelompok relawan. Kelompok ini bertugas menghimpun dana dari masyarakat dan memberdayakannya untuk kegiatan sosial keagamaan yang telah disepakati bersama. Metode yang digunakannya menggunakan metode partisipatif melalui mekanisme kolektif kolegial. Model penghimpunannya sebagai berikut:

a. Keluarga sadar ZIS (Kadar ZIS), yakni sosialisasi dan dakwah zis dilakukan secara rutin melalui forum tahlil/ istighatsah/ majelis taklim.

b. Menyisihkan Rp. 500/ hari di toples, yakni pembelian toples untuk diantarkan ke masingmasingg kepala keluarga. Dengan toples tersebut, warga masyarakat bisa menyisihkan Rp. 500 setiap pagi sebelum belanja keluarga

c. Pengambilan uang zis tiap pekan, biasanya satu relawan mendatangi rumah antara 40-70 kepala keluarga. Tiap pemasukan dari kepala keluarga dicatat secara ketat dan rapi

d. Rekapitulasi dan laporan pengurus, buku besar keuangan dicatat dan diserahkan kepada ZIS.

e. Penyimpanan uang di bank yang disepakati pengurus ZIS. Uang ini kemudian anggarkan secara ketat dan dilaporkan secara khusus kepada pembina dan pimpinan. Hasil sedekah ini dialokasikan untuk beberapa hal, yakni amil zakat, pendidikan, kesehatan, keagamaan, infrastruktur, dan sosial. Yang tidak kalah hebatnya adalah pengembangan mendorong terciptanya wirausaha maju sehingga warga NU yang biasanya monoton bisa berangsur menjadi muzaki (Huda, 2017: 99).

Tokoh ketiga, sekaligus tokoh yang sangat berpengaruh luas bagi gerakan sedekah secara 
ljtihad: Jurnal Wacana Hukum Islam dan Kemanusiaan, Volume 18, No. 1, Juni 2018: 17-31

umum ialah pejabat pemerintah. Fungsi pejabat pemerintah adalah menjamin legitimasi gerakan sedekah, sekaligus membangun sinergi antara ulama dan umara (pemimpin negara) dalam mengembangkan hegemoninya. Menurut Abdul Basith, jika gerakan ini tidak didukung oleh pemerintah, maka gerakan ini akan sangat kesulitan seperti yang terjadi pada masa masa awal membangun. Dari 10 tahun periode awal, gerakan sedekah tanpa adanya dukungan pemerintah hanya bisa berjalan paling lama satu tahun (Huda, 2017: 77).

Pada aspek kekuasaan, hubungan agama dan politik diwujudkan melalui tiga regulasi pemerintah Kabupaten Sukabumi. Pertama, surat edaran Bupati Nomor 3 tahun 2016 tentang gerakan shalat subuh berjamaah dimasjid. Surat edaran ini menginstrukstikan organisasi perangkat daerah (OPD) melaksanakan shalat subuh di masjid. Melalui surat edaran ini, di Kabupaten Sukabumi dibentuk gerakan subuh mengaji. Regulasi ini merupakan bentuk simpati atas gerakan subuh mengaji yang dilakukan Abdul basith di pengajian ke pengajian. Dalam gerakan subuh mengaji, isinya tidak hanya berupa shalat Subuh, tetapi juga diadakan sosialisasi zakat, infak, sedekah. Setelah selesai pengajian, relawan ZIS akan membagikan toples untuk diisi jamaah. Untuk memantau pelaksanaannya di lapangan, pemerintah juga membentuk tim penggerak di tingkat kecamatan, desa, kelurahan.

Kedua, surat edaran Nomor 1 tahun 2016 tentang pengumpulan zakat, infaq, shodaqoh (ZIS) pengusaha penyedia barang dan jasa. Pada aplikasinya, pemerintah kabupaten mendatangi sejumlah perusahaan untuk mengajak karyawan dan para pemilik usaha untuk berzakat di lazisnu. Adapun ketiga, bupati Sukabumi mengeluarkan peraturan bupati no. 35 tahun 2016 tentang pengelola infak, sedekah, dan bantuan sosial keagamaan lainnya. Peraturan ini menjadi tonggak penting bagi tradisi zakat, infak, dan sedekah dan terbukti telah menggeliat di tiga tahun terakhir.

Atas berbagai pengaruh yang diberikan oleh para tokoh, gerakan sedekah lima ratus rupiah ini memberikan dampak pada perubahan sosial berskala luas di kabupaten Sukabumi. Beberapa perubahan tersebut adalah sebagai berikut. Dari gerakan sedekah ini, hasilnya didistribusikan bagi perubahan sosial di masyarakat, seperti sebagai berikut: 1). pembangunan poliklinik dan layanan kesehatan gratis. Pembangunan poliklinik dan layanan kesehatan gratis merupakan salah satu bukti paling besar yang dihasilkan dari gerakan sedekah lima ratus rupiah. Bangunan ini didirikan di atas tanah seluas 1.000 meter persegi pada Februari 
dan diresmikan pada Mei 2015, mendapat respon serius dari Pengurus Besar Nahdlatul Ulama (PBNU) sebagai keberhasilan gerakan sedekah. Melalui poliklinik ini, masyarakat yang mengalami sakit berhak mendapatkan layanan kesehatan secara gratis. Begitu pula dengan dokter dan bidan yang menangani pasiennya tidak mau dibayar penuh sehingga pembayaan poliklinik hanya pembayaran obat saja. Bagi penderita penyakit yang cukup berat, pengurus ZIS memberikan bantuan sesuai kesepakatan (biasanya Rp. 500.000/ pasien) dan melakukan advokasi dana BPJS untuk membantu keluarga pasien yang kesulitan (Huda, 2017: 30-33). 2). Santunan kematian. sebagaimana tradisi kaum Nahdliyin, jika ada keluarga meninggal dunia, pihak keluarga mengadakan talqin, tahlil, dan mengaji Al-Qur'an selama sepekan. Untuk meringankan beban keluarga yang ditinggalkan, sebagian dari dana sedekah dialokasikan untuk mengganti biaya pengajian selama sepekan. Santunan kematian besarnya Rp. 500.000-Rp. 2.000.000 tergantung kondisi ekonomi keluarga yang ditinggalkan. c). Pemasangan lampu-lampu jalan. Penerangan lampu jalan dilakukan pada lokasi gang gang kecil dan jarak antar kampong yang masih belum mendapatkan akses lampu. Biasanya, satu titik lampu menghabiskan dana sekitar Rp. 150.000 yang digunakan untuk membeli tiang besi atau bamboo, kap lampu, kabel kualitas bagus, dan lampu berdaya 25 watt. Adapun aliran listriknya mengambil dari rumah terdekat atau dari penerangan jalan umum. d). Beras untuk kaum miskin. Beras untuk rumah tangga miskin sebenarnya merupakan program pemerintah. Akan tetapi dalam prakteknya, penentuan kriteria keluargaa miskin seringkali menjadi persoalan yang rumit karena tidak sedikit keluarga berkecukupan ingin mendapatkan beras raskin. Karenanya, untuk mengatasi kecemburuan sosial biasanya beras subsidi tersebut perlu ditebus dengan nominal tertentu. Berkaitan dengan beras untuk keluarga miskin, yakni hasil pengumpulan dana sedekah dialokasiakan untuk menebus beras subsidi pemerintah bagi jompo, fakir miskin dan janda yang tidak mampu menebusnya. e). pembiayaan listrik masjid, guru mengaji, dan marbot masjid, baik pembayaraan listrik ke PLN maupun gaji guru mengaji dan marbot masjid. f). Peternakan domba dan pesantren agropreneur, yakni sebagian dari sedekah lima ratus rupiah dan bantuan pemerintah dialokasikan untuk pengembangan peternakan domba dan pengembangan pesantren agropreneur. g). pengembangan konservasi bekerja sama dengan pesantren konservasi Al Amin, misalnya kerjasama penanaman ratusan ribu pohon sengon dengan sistem bagi hasil (Majalah Intisari tahun 2010). 
ljtihad: Jurnal Wacana Hukum Islam dan Kemanusiaan, Volume 18, No. 1, Juni 2018: 17-31

\section{Penutup}

Gerakan sedekah lima ratus merupakan gerakan perubahan sosial masyarakat yang diinisiasi oleh spirit keagamaan. Gerakan ini berupaya untuk melakukan harmonisasi ajaran agama secara vertikal dengan horizontal, antara ibadah dengan pemberdayaan masyarakat. Setelah 16 tahun berjalan, gerakan sedekah lima ratus telah memberikan dampak perubahan bagi masyarakat, baik pemberdayaan agama maupun pemberdayaan sosial, bahkan menjadi inspirasi bagi kebijakan publik di Kabupaten Sukabumi.

Gerakan ini diinspirasi oleh spirit pemikiran agama ke NU-an (fikrah nadiyah), akan tetapi praktek gerakannya dilakukan atas inisiatif para tokoh agama, 4 tahun lebih dahulu ketimbang kelahiran lazisnu di tubuh NU. Artinya, kesadaran keagamaan masyarakat Desa Nanggeran, Kec. Cicurug, Kab. Sukabumi untuk melakukan sedekah telah muncul dari kesadaran masyarakat sebelum ada lembaga agama yang melaksanakannya.

Secara umum, pelaksanaan gerakan sedekah ini ditopang oleh 5 tokoh melalui hegemoni kepemimpinan yang diperankannya, yakni Abdul Basith, relawan, dan pemerintah Kabupaten Sukabumi. Abdul Basith melalui kepemimpinan intelektual dan moralnya sebagai pimpinan pesantren Al-Amin, sekaligus ketua PCNU Kab. Sukabumi mampu memberikan efek besar dalam mengajak masyarakat bersedekah.Relawan memainkan peran sebagaipihak mencari, mengumpulkan dan mendistribusikan sedekah. Adapun pemerintah daerah berperan menjadi stimulus dan legitimasi gerakan sedekah.

Perubahan sosial yang ditimbulkan dari gerakan sedekah ialah pembangunan poliklinik dan layanan kesehatan gratis, santunan kematian, pemasangan lampu-lampu jalan, beras untuk kaum miskin, beasiswa anak yatim, pembiayaan listrik masjid, pembiayaan gaji guru mengaji dan marbot masjid, peternakan domba dan pesantren agropreneur, pengembangan konservasi alam. Adapun kebijakan publik yang lahir dari gerakaan sedekah lima ratus rupiah adalah, surat edaran Bupati Nomor 3 tahun 2016 tentang gerakan shalat subuh berjamaah dimasjid, surat edaran Nomor 1 tahun 2016 tentang pengumpulan zakat, infaq, shodaqoh (ZIS) pengusaha penyedia barang dan jasadan peraturan bupati no. 35 tahun 2016 tentang pengelola infak, sedekah, dan bantuan sosial keagamaan lainnya. Peraturan ini menjadi tonggak penting bagi tradisi zakat, infak, dan sedekah dan terbukti telah menggeliat di 3 tahun terakhir. 
Islam dan perubahan sosial: Gerakan sedeqah lima ratus rupiah dan perubahan sosial... (lji Jaelani)

\section{Daftar pustaka}

Gaus AF, Ahmad. Filantropi dalam Masyarakat Islam, Buku Ini Juga Menginspirasi CSR CSR Perusahaan untuk Mengubah Paradigma dalam Aktivitas Filantropi. Jakarta: Elex Media Komputindo, 2008.

Ghazali, Adeng Muhtar. Ilmu Studi Agama. Bandung: CV. Pustaka Setia, 2005.

Hendarto, Heru. Mengenal Konsep Hegemoni Gramsci, dalam Diskursus Kemasyarakatan dan Kemanusiaan. Jakarta: Gramedia,1993.

Huda, Syamsul, dkk. Membumikan Sedekah, Belajar dari Cicurug Sukabumi. Jakarta: NU Care-Lazisnu, 2017.

Kahmad, Dadang. Metode penelitian Agama; Persepektip Ilmu Perbandingan Agama.Bandung:Pustaka Setia, 2000.

Kahmad, Dadang. Sosiologi Agama. Bandung: PT. Rosdakarya, 2000.

Linawati. Konsep dana dalam Budha dan Sedekah dalam Islam. Skripsi. Semarang: Fakultas Ushuludin IAIN Walisongo, 2004.

Mukti, K.Wijaya. Belajar Menjadi Bijaksana. Jakarta: Yayasan Dharma Pembangunan, 1993.

Nottingham, Elizabet K. Agama dan Masyarakat. Jakarta: Raja Grafindo Persada, 1996.

O’dea, Thomas F. Sosiologi Agama; Suatu Pengenalan Awal. Jakarta: Rajawali Pers, 1996.

Patria, Nezar dan Andi Arief. Antonio Gramsci; Negara dan hegemoni.Yogyakarta: Pustaka Pelajar, 2009.

Sabet, Amr. Religion, Politics and Social Change: A Theoretical Framework, dalam Jurnal Religion, State \& Society, Vol. 24, Nos. 2/3, 1996.

Wach, Joachim. Ilmu Perbandingan Agama, Inti dan Bentuk Pengalaman Keagamaan, Terj. Djamannuri. Jakarta: Rajawali, 1992.

\section{Sumber berita online}

http:/ / c3i.sabda.org/, Ligon Duncan, Ten Principles of Christian Giving, 5 Desember 2011. http://alkitab.sabda.org.

https://nucarelazisnu.org/sejarah/. 